\title{
Article
}

\section{From a lady to a lost 'Prole': Girls in the city in Polish cinema of the 1960 s and early 1970 s}

Mazierska, Ewa Hanna

Available at http://clok.uclan.ac.uk/25178/

Mazierska, Ewa Hanna ORCID: 0000-0002-4385-8264 (2018) From a lady to a lost 'Prole': Girls in the city in Polish cinema of the 1960s and early 1970 s.

Film, Fashion \& Consumption, 7 (2). pp. 115-130. ISSN 2044-2823

It is advisable to refer to the publisher's version if you intend to cite from the work. http://dx.doi.org/10.1386/ffc.7.2.115_1

For more information about UCLan's research in this area go to http://www.uclan.ac.uk/researchgroups/ and search for < name of research Group>.

For information about Research generally at UCLan please go to http://www.uclan.ac.uk/research/

All outputs in CLoK are protected by Intellectual Property Rights law, including Copyright law. Copyright, IPR and Moral Rights for the works on this site are retained by the individual authors and/or other copyright owners. Terms and conditions for use of this material are defined in the policies page.

\section{CLoK}

Central Lancashire online Knowledge www.clok.uclan.ac.uk

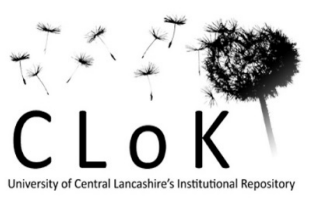




\section{From a Lady to a Lost 'Prole': Girls in the City in Polish Cinema of the 1960s and Early 1970s}

The term 'girl' is by no means neutral, but culture specific. Someone called a 'girl' in one decade or place might not be classified as 'girl' in another. The fact that this special issue is focused on the Sixties demonstrates that during this decade not only girls themselves changed but also the very concept of 'girlhood' underwent a profound transformation. I will argue that at this time 'girl' started to signify less a specific age and more a state of mind: willingness to have fun, 'hang on to irresponsibility, or childhood' (Diski 2009: 5) and being open to new experiences, including sexual ones, greatly facilitated by the availability of the 'pill'. To that we shall add that the Sixties was a 'time of striving for individuality' (ibid.) and this search was encouraged by a greater availability of consumer goods, especially home equipment, which granted women more free time and a greater choice of clothes. This was a consequence of the end of postwar austerity and an unprecedented improvement in living standards, ensured by the new political order, which brought almost full employment and expansion of the welfare state.

However, such claims are usually directed towards western culture. Much less has been written about girls in the countries of state socialism. To make up for this gap, I will consider representations of girls in two Polish films from the beginning of the 1960s, Do widzenia, do jutra (Good Bye, Till Tomorrow, 1960), directed by Jerzy Morgenstern and Niewinni czarodzieje (Innocent Sorcerers, 1960), directed by Andrzej Wajda and two from the beginning of the 1970s, Seksolatki (Sex-Teenagers, 1971), directed by Zygmunt Hübner and Dziewczyny do wzięcia (Girls to Pick Up, 1971), directed by Janusz Kondratiuk. This will allow me to capture the moment when 'girls' first appeared in Polish cinema, how they changed over the decade and how this transformation, which I will call 'democratisation of girlhood' was assessed by the filmmakers.

I am turning to film because it is both an important cultural document and an effective tool for transmitting and transforming the dominant ideology. Specifically, I will talk about 'girls in the city' as it is easier for young women to be 'girls' according to the above definition: have fun and experience something new and unexpected, than in a province, where social control is greater. In my discussion I will underscore the issue of class, as the representations of the characters in the aforementioned films were strongly affected by assumptions about their class background. Before I turn to film, however, let's provide a context of the films.

\section{$\underline{\text { Poland of small stabilisation and its cinema }}$}

In 1956 Władysław Gomułka became the First Secretary of the Polish United Workers' Party (the PZPR), hence de facto the political leader of the country. Gomulka got this position after the death of Joseph Stalin and his Polish counterpart, Bolesław Bierut, who died in 1956. Gomułka was initially seen as a true leader of the Polish nation, independent from Moscow, with a mandate to reform the country's politics, economy and culture. However, after a period of reforms, known as the 'thaw', which lasted till the end of the 1950s, there followed a time of economic and arguably cultural stagnation, known as the 'small stabilisation'. This term is borrowed from the play by Tadeusz Różewicz, Świadkowie albo nasza mała stabilizacja (Witnessses or Our Small Stabilisation), published in 1962. Its protagonists, He and She, define 'small stabilisation' as a time of diminishing of requirements and responsibilities. During small stabilisation morality takes a back seat, because people are preoccupied with material pursuits. However, they do not complain because they are anxious not to lose what they achieved (Różewicz 1986). The playwright is critical about such an attitude to life, seeing in it a road to atrophy of feelings, even dehumanisation. However, it 
can be viewed more positively, and true to the literal title, as a reflection of the times of peace and stability, after the hardships of the Second World War and Stalinism, when people were eventually allowed to forget about politics, enjoy their everyday existence and be individuals rather members of a group (Kurz 2010). Needless to say, during WWII or Stalinisation it was next to impossible to be a 'girl'. Indeed, some of the most important films about this period, such as Andrzej Wajda's Kanat (Kanal, 1958) about the Warsaw Uprising, mourn the premature adulthood of young Polish men and women, indeed that they would never become (careless) boys and girls, because they die in the Warsaw sewers, trying to escape the Nazis. By contrast, in the films from the 1960s, such as Roman Polanski's Nóż w wodzie (Knife in the Water, 1962) and Jerzy Skolimowski's Rysopis (Identification Marks: None, 1964), we see characters exploring their surroundings and sometimes even getting lost, in the knowledge that they have time to do so and that being on the wrong path will not be punished too harshly (Mazierska 2015).

The joy of walking aimlessly, meeting strangers and participating in youth culture was felt most strongly in three cities: Warsaw, Kraków (Cracow) and Gdańsk, because these three cities were culturally the most developed. In Warsaw thanks to being Poland's capital, by this time largely re-built from the ruins of the war, Gdańsk because of its cosmopolitan character thanks to being a coastal town and Kraków due to being the ancient capital, and geographically and culturally close to Vienna. In the 1960s the importance of Gdańsk was particularly pronounced, as in its cabarets and student clubs Polish rock was born. In short, Gdańsk was the place to be in Poland, if one wanted to be where 'things happened'. This is reflected in a large number of films set in Gdańsk, including two discussed in this article.

Still, the 1960s was not a time of consumerism, as it is normally understood: indulging in the purchase of material goods and creating one's identity by attaching oneself to specific brands. By and large, Poland's economy in the 1960s (in common with the whole of the Eastern bloc) was an economy of shortages. Władysław Gomułka was ostensibly against consumption, equating it with 'eating up' one's future (Morawski 2007: 329), therefore industrial expansion was his priority, as it had been Bierut's. For this reason, he was also against Poland developing a car industry on a large scale. Consequently, cars were rarely seen on Polish streets and the prices of clothes, shoes and kitchen utensils were very high in comparison with the price of food. The history of Polish fashion post-1945 demonstrates this position well. In 1958 the first Polish fashion label, Moda Polska (Polish Fashion) was set up, but its principal goal was to present Polish fashion design on the international stage, rather than quench the appetite for nice clothes of the indigenous population. As a specialist in the history of Polish fashion, Małgorzata Możdzyńska-Nowotka maintains, throughout its history, Polish women went to Moda Polska salons to look at clothes, rather than to buy them, because prices there were 'astronomical' (quoted in Piekarska 2016: 10). The virtual lack of importation of consumer goods from the West only added to the problem.

By the early 1960s there were several women's magazines in Poland, but in the 1960s they focused on emancipating women through joining the workforce, especially choosing technical jobs and encouraging men to share household chores and child-rearing (Wójcik 2014). In comparison with the 1950s, Polish women also had more opportunities to read about fashion in the popular press. Among the most popular source of information was a column devoted to fashion in the cultural magazine Przekrój, written by Barbara Hoff. At this time, however, fashion columns largely provided information about what other (western) women were wearing and how Polish women can emulate them, using a sowing machine and one's ingenuity, rather than what one could buy on the Polish high street (Piekarska 2016). It 
was only in the early 1970s when Barbara Hoff moved from advising about fashion to actually designing fashionable clothes, to be sold at Domy Centrum (the Central Warehouse) $)^{i}$, virtually in very centre of Warsaw and became the most successful fashion designer in Poland, that fashion became a mass phenomenon. This happened against a background of the profound political, social and economic changes, when Edward Gierek became the new First Secretary of the PZPR and Poland became the main consumer centre of the socialist East, in large part thanks to cheap foreign credit. At the time women had a chance to show their independence and individuality not only through having a career, but also specific attire.

The change from public to private, associated with Gomułka's era is also reflected in the film titles. Rather than having titles which either pointed to the domination of a collective over the individual or to the high Romantic ideals of fighting and dying for one's country, which pertained to the 1950s (for example Two Teams, Generation or Ashes and Diamonds), we find films with 'marriage' in the title, for example Matżenstwo z rozsadku (Marriage of Convenience, 1966) by Stanisław Bareja or a name, like Jowita (1967) by Janusz Morgenstern. The authorities themselves encouraged filmmakers to make films about everyday life, which will be truthful, yet optimistic and praising the socialist status quo, publishing a document which provided new guidelines for film production in Poland (Uchwała 1994). In my discussion I am not arguing that in the 1960s filmmakers slavishly responded to this call, but that there was a certain fit between what the authorities demanded, namely for people to focus on their everyday existence, and what the filmmakers wanted to show. This is reflected in the waning of socialist realist films, set at the sites of production, and films about the Second World War, offset by an increase in certain types of character who were barely present in the previous decades, such as students and the 'intelligentsia' (doctors, journalists), which were the socialist equivalents of the western middle class. The films which I will discuss in the next part of my essay testify to this shift.

How to be a lady: girls at the beginning of the 1960s

Good Bye, Till Tomorrow was the feature debut of Janusz Morgenstern (1922-2011), a director who distinguished himself in making films about unrequited love, and later a popular television series. It was based on a short story written by Zbigniew Cybulski, then the greatest Polish male star thanks to his portrayal of Maciek in Andrzej Wajda's Popiót $i$ diament (Ashes and Diamonds, 1958) and the male lead in Good Bye, Till Tomorrow. The film shows a day in life of Marguerite, the daughter of the French Consul in Poland, which she spends in Gdańsk, among young Polish people living there. She particularly charms one of them named Jacek, played by Cybulski, who keeps her company during her travels. She is shown playing tennis, visiting a students' theatre where rehearsals take place, a club, a market where she buys some souvenirs and a church. When evening comes, Marguerite returns to the Embassy, where she lives, leaving Jacek on the other side of the gate.

Apart from Cybulski's story, there were other models or hypotexts for Morgenstern's film. The character of Marguerite was based on Françoise Grisard, the real daughter of a French diplomat. Françoise spent some years in Poland and was known for mixing with the Polish 'bohemia' of the 1950s. The main cinematic model was Jean-Luc Godard's debut feature À bout de soufflé (Breathless, 1960) (Ostrowska and Rydzewska 2007: 189), but one can also notice references to Bonjour tristesse (1958) by Otto Preminger. Both films presented a new type of young woman, on both occasions played by Jean Seberg: very elegant and stylish, focused on pleasure, and treating sex as a vehicle for personal fulfilment rather than a means to have a family and stable and affluent life. Yet, Seberg's heroines were not openly rebellious against the older generation nor independent, as they lived off their 
families, favoured male over female company and attempted to charm men with their exquisite clothes and perfect manners.

This is also the case with Marguerite. Marguerite, like Patricia in Godard's film, acts on a whim and tries various identities. For example, we see her engaging in an impromptu dance with a young man (played by Roman Polanski) on a tennis court and entering a church and pretending to have a wedding there. There is no sex in Morgenstern's film, but this might reflect more the requirement of censorship than the girl's chastity. Marguerite's behaviour is also typical of tourists, as their lives tend to be less strictly organised than that of workers or fighters, especially if they are individual rather than mass tourists, as is her case. She is presented as a tourist in two senses. Firstly, she is French, therefore not native to the city and the country where she finds herself. Secondly, she describes herself as a traveller, who never settles anywhere and for whom changing locations is natural and easy. She mentions that when bored she boards a car or train and leaves, and she is surprised that other people do not do the same when they are fed up with their daily routine. Such mobility was naturally not available to Poles, living behind the 'Iron Curtain' and even only a small proportion of upperclass westerners could indulge in it. There is no doubt that Marguerite is upper class; her being the daughter of the French Consul is the clearest sign of it. It can be added that at the time the film was made, France was for Poles at the top of the unofficial hierarchy of western countries. There are also other markers of her high class position. She is the prettiest of the girls we see in the film and her clothes are most elegant, bringing to mind those worn by Seberg, as well as Grace Kelly in her Hitchcock films. To that we can also add various objects she uses, such as a tennis racket, a small, well-groomed white dog and a white foreign car. She takes them for granted, paying them little attention and leaves them behind to embark on a 'new leg' of her journey. Her use of these 'fashion accessories' adds to her attractiveness, as at the time Polish girls would not be able to afford them and most likely they would like to show them off, rather than treat them with indifference. The other girls shown in the film look at best as Marguerite's poor imitations. Her exclusive style, foreignness and touristy outlook are the main reasons Jacek finds Marguerite so attractive. Watching Good Bye, Till Tomorrow at the time of its premiere could be compared to visiting a salon of Moda Polska or studying Hoff's fashion column in Przekrój - it rendered fashion fascinating, but ultimately unattainable. As I will argue in due course, this situation would gradually change.

Morgenstern not only shows that Marguerite is a tourist, but that the city deserves her attention. To an even greater extent than Breathless, Good Bye, Till Tomorrow foregrounds the historical centre of the city (Näripea, Mazierska and Kristensen 2016: 58). The opening scene of the plot presents Jacek against the background of the medieval Old City bordering the Mołtawa River, including the iconic port crane, called Żuraw (the Crane). In this very early shot we thus see Gdańsk at its most beautiful. Nothing obscures its beauty, no signs or litter on the streets or passers-by, according to the rule that tourists sites tend to be decontextualized and beautified (Albers and James 1988: 154-55). Throughout the film the same scheme operates, privileging the most iconic buildings and objects of the city, such as Dwór Artusa (King Arthur's Court), the Neptune Fountain or the Marian Church. Their importance is accentuated by Jacek's pointing them out to Marguerite, describing their history as if he was her (and by extension us, the film viewers'), travel guide. This feature was noted by reviewers who used adjectives such as 'showy' to capture the work of the film's cinematographer, Jan Laskowski (Bielicki 1960: 6). Souvenir stalls in the city centre, and the beaches and an open-air café also form part of the 'tourist paradise'. Notably, the beach sequence was in fact shot in neighbouring Sopot, yet there is no indication that the action is diegetically moved to Sopot, which gives the misleading impression that the centre of Gdańsk is on the Baltic coast. The cutting out of the road between the Old City and the Baltic Sea 
equals cutting out the less attractive parts of the town. There are also no images of the new estates with high-rise blocks or of public transport. A large part of the narrative is set in sites of art, such as a students' puppet theatre and an exhibition of contemporary art set on the coast, near the beach. The modernist sculptures bring to mind modernist art presented in Breathless and many other of Godard's films. One can even get an impression that the building by which the sculptures are exhibited looks like a miniature version of the Pompidou Centre.

Yet, as a well-travelled tourist, the Consul's daughter seems a bit bored with what Gdańsk has on offer. Its museums and exhibitions do not appeal to her, because she knows places of this type elsewhere. At the same time, Marguerite is an object of the gaze of the natives, which, like the tourist gaze, is based on a perceived difference between 'us' and 'others'. Marguerite herself is 'decontextualised', because she belongs to an exclusive no man's land populated by diplomats and their families. Marguerite herself plays the part of a bemused tourist, allowing the natives to take care of her. She comes across as passive, but not because she is submissive, but because such a strategy allows her to yield a maximum of pleasure with a minimum of effort. Although she enjoys Jacek's advances, ultimately, she does not invite Jacek to her apartment and enter her territory, leaving him on the other side of the gate, which can be read as a metaphor of the treatment of Poles or Easterners at large by the West (Ostrowska and Rydzewska 2007: 190; Näripea, Mazierska and Kristensen 2016: 59).

The actress playing Marguerite was Teresa Tuszyńska. Although she was herself of a modest background, following her role in Morgenstern's film she epitomised an upper-class Polish girl; who in English will be described as an 'It Girl'. Tuszyńska was not only an actress, but also a model, presenting the couture of the previously mentioned Moda Polska. Her beauty and style was so remarkable that she received proposals to play in foreign films. She also became the only Polish actress to appear on the cover of the British magazine Show. Ultimately, however, she was not interested in a career on screen. When Roman Polanski (her dancing partner in Good Bye, Till Tomorrow) brought to Warsaw a French producer to engage her in a film, she did not come for the meeting. She was also known for missing other important appointments, as well as coming late for shooting. Not surprising, her acting career was relatively short. It is worth noting that although Tuszyńska and Cybulski were cast in the roles of a 'girl' and a 'boy', there was a significant difference in age of these actors.

Tuszyńska was only 18, Cybulski 33, which was commented on with derision by some reviewers. In my opinion, this difference to some extent reflects on a wider rule that male actors tend to have a longer career in film than men, but also that Polish cinema of the 1960s was truly interested in young women. This, however, did not amount to allowing them to represent themselves. Although the main character in the film is female, otherwise Good Bye, Till Tomorrow is a very masculine, being directed, scripted and photographed by all-male crew. The only exception was a costume designer, Katarzyna Chodorowicz, one of the most distinguished in her profession, who in the 1960s made costumes to most visually stunning films of this period, such as Wszystko na sprzedaz (Everything for Sale, 1968) by Andrzej Wajda.

Against the background of Good Bye, Till Tomorrow, Innocent Sorcerers comes across as less 'snobbish', as all the characters in the film are Polish. It is worth mentioning here that the film's director, Andrzej Wajda (1926-2016), is regarded as the Polish 'national' director thanks to his ability to capture the spirit of the time; his films are always about specific generations, entering social and cultural scene at a particular moment, as signalled by the title of his first full-length fiction film, A Generation. Moreover, many of his works take issue with events of paramount importance for Polish history, such as wars and uprisings which reveal what can be described as the 'Polish fate': loss, martyrdom and death. Wajda 
also directed few 'lighter' films and Innocent Sorcerers is one of them. Paradoxically, despite its light character Innocent Sorcerers had problems with censorship; its premiere was postponed over a year and it only happened when Wajda changed the film's ending on the request of the censors. The film was scripted by Jerzy Andrzejewski, a famous author, who was also author of the script for Ashes and Diamonds and Jerzy Skolimowski, future director of some of the most important Polish films of the 1960s. Skolimowski, who was only 22 at the time, was invited to join Andrzejewski, because he was seen as somebody who understood the 'youth'.

Innocent Sorcerers is about a 'boy' and a 'girl' whose true names we never learn, because they adopt fake identities 'Pelagia' and 'Bazyli'. In the course of the narrative we learn that 'Bazyli' is a young doctor who in his spare time plays the drums in a jazz band in Warsaw clubs; she is probably a secondary schoolgirl, a teenager, but we do not know for sure. They visit a student club together, and spend a night in 'Bazyli's apartment, showing erotic interest in each other, but without making love. In the morning 'Pelagia' leaves, but then returns to 'Bazyli', as if to prove that she fell in love with him and is ready to confess it, shedding the mask of a cynical girl. This ending was apparently forced on Wajda by the censors, who did not approve of the characters being 'unproductive', by spending a night on talk, which led nowhere. Wajda's own favourite ending showed 'Pelagia' back at school, in her school uniform, among many other girls looking exactly like her. This was meant to demonstrate that, although she appeared unique, she was in fact one of many ordinary girls, trying to be somebody else. If this was the case, it would confirm the opinion that Wajda was always interested in generations and wider social trends than exceptions to the norm.

The different endings of the film reflect confusion about young women in this period. Should they be equal to men and decide who are their partners for sex and life or should they be subservient to men? In this film Wajda seemed to oscillate between granting the girls autonomy and seeing them as male toys and a mirror in which the men can admire themselves. Also, the fact that we know so much more about 'Bazyli' than 'Pelagia' suggests that the male character is more important to the author of the film than the female character. Another explanation is that for the mostly middle-aged men, making this film, girls were an enigma. Due to the fact that we see 'Pelagia' only in the house of her boyfriend to-be, the issue of her class is occluded. However, her elegant clothes, again in the style of Jean Seberg and Grace Kelly, and her sophistication suggest that she does not come from a working class or peasant background, but rather from an intelligentsia class. Male clothes in Innocent Sorcerers are less fancy (as this would also be the case in western films from this period), but it is clear that men in this film also pay attention to their appearance and their surroundings. 'Bazyli's' hair is bleached, and the camera ponders on the luxury objects he and his friends use, such as a tape recorder and a motorcycle. As in the case of Good Bye, Till Tomorrow, while the 'girl' in the film was played by a truly young woman, 21-years old Krystyna Stypułkowska with no prior acting experience, her partner was played by 33-old Tadeusz Łomnicki, who by this point had already played in a large number of films and would become one of the greatest stars of Polish cinema.

While Morgenstern's film invited comparison with À bout de soufflé, Innocent Sorcerers can be compared to the films of Eric Rohmer, where men and women spend a long time talking, often processing their lack of commitment to the opposite sex. In the case of Rohmer's character, this has often to do with previous romantic disappointment. In the case of Wajda's protagonists, it seems more to do with their desire to prolong one's adolescence.

In common with Good Bye, Till Tomorrow, Innocent Sorcerers shows that Warsaw is a welcoming place, where youth culture is thriving. However, it is a less touristy film, as most of the action is set indoors and it uses the outdoors largely as a backdrop for action, rather than something to contemplate. Nevertheless, the film makes the point that, although 
Warsaw was not entirely rebuilt after the wartime destruction, it is rising from the ruins and there are not only more apartments, but places to hang out. These places, namely students clubs, however, have a distinct non-working class character. One can imagine that only people behaving in a specific way were allowed there. This was one reason Wajda's film attracted criticism. Many reviewers argued that the film offered an inauthentic image of Poland because a very low percentage of Polish young men and women were able to spend their lives 'between Manekin and Stodoła' (the two students' clubs featured in Innocent Sorcerers) (Lichniak 1960).

However, the criticism concerning the lack of realism in representing Polish culture of this period was misplaced, as the films were 'aspirational', not unlike the fashion columns, penned by Barbara Hoff in Przekrój. Their point was not to show how ordinary girls and boys lived at the turn of the two decades, but how they wanted and should be allowed to live. Indeed, as the decade progressed, we find more and more girls who were well groomed, but were of a lower-class background. Of them the greatest popularity gained was those played by Elżbieta Czyżewska, probably the greatest Polish female star of the 1960s. For example, in Stanisław Bareja's Małżeństwo z rozsadku (Marriage of Convenience, 1966), Czyżewska plays the daughter of small capitalists (effectively a criminal underclass at this period), who pretends to be a daughter of diplomats and wins the heart of a painter. Her success in passing for somebody of a higher class points to the democratisation of 'good style' in Poland. However, as I will argue in the next section, this rise of the working class provincials as fashion icons led to a backlash on the part of the filmmakers.

No escape from the boredom of the province: girls at the beginning of the 1970s

Sex-Teenagers and Girls to Pick Up are liminal films because they were made at the beginning of the 'Gierek decade'. At the time the country only started to be transformed by his policies, which included a significant rise in living standards and consumption, yet also growing inequalities, with the provinces lagging behind the cities and social mobility slowing down. It was a time when Polish fiction cinema changed significantly, due to adopting a more observational style associated with television and documentary film. This shift would be most recognised and lauded in the second half of the 1970s, in the movement known as the Cinema of Moral Concern, but the films discussed in this part of my article already foretell it; not least because one of them, Girls to Pick Up, was produced by television.

The main difference between these two films and those previously discussed from the perspective of representing 'girls' can be deduced from their very titles. Seksolatki and Girls to Pick Up are very explicit about their subjects. 'Seksolatki' is a version of the term 'nastolatki', which is the plural of the Polish version of a 'teenager'. The title suggests that Polish teenagers of the early 1970s have sex. This is indeed the case in the film which focuses on a couple, made up of Ania who is sixteen and Tomek who is seventeen. They are both pupils in technical colleges in Gdańsk. First they live in different dormitories, but try to find a place where they can stay together. They succeed in renting a room by pretending that they are siblings. However, the lie is revealed and the head of Ania's school forces her to leave her accommodation and move back to the boarding school. Tomek is likewise forced to return to his old accommodation. Separated, they turn to their parents for help, but to no avail. Tomek's widowed father refuses to give him money on the grounds that he does not earn enough and he found a new partner. Ania's parents try to force the couple to split up, regarding their behaviour as scandalous. Only when the girl attempts suicide, they change their mind and find accommodation for the couple in a large apartment of Ania's aunt. Ironically, by this point their relationship disintegrates. Ania gets bored in Tomek's company and starts to look for other attractions. At one point she attends a party in somebody's house 
(so called prywatka), which turns into an orgy. She barely avoids being raped by some older men. It happens at a time when Tomek is looking for her in the city on a borrowed motorcycle. The couple make up, but eventually go their own ways. The message seems to be that the youngsters started their sex life too early to have any chance of success.

Unlike the two films discussed previously, in Sex-Teenagers the girl is a leading force in the film. She is the one who demands from Tomek that they find a place where they can live together and puts pressure on their families to acquiesce to the couple's needs. She also makes the decision to leave Tomek when she becomes bored with him. Although immature in many ways, ultimately she comes across as more strong-headed and independent than her partner. There is also a certain development about Ania's character, which can be mapped onto the Polish postwar history. Initially, the girl yearns for domesticity, for having a boyfriend and a place to live. Later, however, she wants to meet new people and enjoy herself, without thinking about the future. This is reflected in the spaces she occupies. First we see her in enclosed spaces and in open places where she is with Tomek. This reflects their desire to be together, which is difficult to fulfil due to their poor living conditions. In the last part of the film, however, she is in the city centre, among crowds of people, where Tomek feels uncomfortable. Hence, in some kind of reverse of female and male roles, as traditional Polish culture prescribes them, yet reflecting the 1960s sexual revolution, Ania is not a domestic, but a 'wild animal', while the man enjoys domesticity and stability.

Ania and Tomek's relationship is disapproved of by their parents, teachers, even friends. The boys living in Tomek's dormitory tease him for giving in to female pressure and not even one exerted by a proper (adult) woman, but a 'girl'. Teachers regard their relationship as something which will prevent them from concentrating on their school work. The parents are afraid that it will affect their reputation. Such criticism is not only depicted in the film, but ultimately embraced by the filmmakers, who show that their liaison disintegrates because the girl does not want to live 'like a wife'. That said, the film offers no positive alternative to domestic life. If Ania wants to have a life outside school, she is either condemned to having a stable and ultimately boring boyfriend or spend her time in the company of older sleazy men. It is worth mentioning that the company of other women is not presented as a viable alternative to having a boyfriend. Other girls from Ania's class do not like her because of her personal situation and when she eventually rekindles friendship with one of them, she takes her to a sleazy party. Adult people in the film also cannot be regarded as role models for the youth.

Sex-Teenagers appeared to be a bold film in touching on the subject which was kept off-screen in the previous decade. It was widely anticipated by the Polish audience, as testified by the fact that its script was serialised in the Polish magazine Sztandar Młodych (Stawecki 1972: 12). Ultimately, however, it comes across as heavy-handed and lacking in psychological realism, mostly because the characters lack any depth and change their views and behaviour very quickly, without any convincing motif (Helman 1972; Skwara 1972; Stawecki 1972). This fact can be attributed to the authorship of this film. The film was scripted by Aleksander Ścibor-Rylski, regarded as a leading Polish scriptwriter of the state socialist period. However, by the time he wrote Sex-Teenagers, he was in his forties and most likely did not have much to do with teenagers. The film's director, Zygmunt Hübner (19301989), was of the same generation. Consequently, the film reflects more what the middleaged men thought about young men and women of this period than what they might have learned about them from direct contact or reading their diaries (Helman 1972). The gap between the filmmakers and their subjects is underscored by the fact that the soundtrack to Sex-Teenagers was jazz music and a song by Irena Santor, a singer whose fans belonged to 
the older strata of the Polish society. Hence, it cannot be regarded as a very reliable document about the changes in popular culture of this period. That said, the filmmakers do not mock their characters. This is the more remarkable as the main parts were played by amateurs of the same age as their characters. Only in the sex scene was the girl who played Ania replaced by a double.

In the two films from the beginning of the 1960s it is difficult not to pay attention to the clothes worn by the female characters. By contrast, in Sex-Teenagers the clothes are less remarkable. They are not exquisite, but mass produced, perhaps reflecting the fact that in the 1970s Poland tried to make up for the decades when consumer goods were in short supply and expensive by producing them faster and in larger quantities.

Unlike in Good Bye, Till Tomorrow, Gdańsk in Sex-Teenagers does not come across as a place with a thriving popular culture. We see no clubs or restaurants and people meet in their houses. This might be a reflection of the characters, whose social background does not allow them to fully engage with what the city has to offer. For example, not being university students they might not be let into students clubs and amateur theatres, or lack information about what is on offer there. It can also be seen as a sign of the Zeitgeist. By the late 1960s television became the most common form of entertainment in Poland, keeping people of all ages indoors. It is also worth adding here, that unlike Wajda and Morgenstern, who gained fame thanks to their cine-films, Zygmunt Hübner was predominantly a theatre director and director of 'television plays', a genre flourishing in Polish television in the 1960s and 1970s, marked by predominantly indoor settings.

My last example, Girls to Pick Up was directed by Janusz Kondratiuk (1943-), a filmmaker who, like Hübner, by this point and throughout his entire career was working in television, directing television plays and shorter television films, typically presenting a specific situation, unfolding within one day, as is the case of Girls to Pick Up. However, unlike Hübner, who had a penchant for static shots and theatrical dialogue, Kondratiuk was more of a 'television animal', feeling the camera and having an ear to the way people spoke on the streets.

In contrast to all previous films discussed in this article, in Girls to Pick Up we do not see one, but three girls in the city. They are all working class, most likely labouring in a factory not far from Warsaw. During the day the story takes place, they travel by train to the capital in search of fun and (sex) partners. They want them to be of a higher class than themselves, ideally a doctor or an engineer. It is likely that such a dream also pertained to Polish girls in earlier decades, but it will be unlikely to appear on screen, because up to this point the working class was officially hailed as the avant-garde of the society, even though in practice its economic and social status was low. Although the girls are clearly open to seduction by the opposite sex, they do not want to admit it to anyone, even each other, and they even reassure themselves that if somebody tries to pick them up, they will say that they will not make acquaintance on the street. This leads to a humorous situation when two men (who seem to know the girls from a previous encounter) approach them in an underground passage, and when rebuked, tell the girls that 'this is not a street'. Such dialogues mark the lack of skills in courtship on the part of both men and women. Unlike the characters in the films by Morgenstern and Wajda, those in Kondratiuk's film do not know how to play 'identity games'. Indeed, playing them ineptly only reveals their true, working class identity.

The girls in the films by Morgenstern and Wajda looked very attractive without making any effort. By contrast, the girls in Girls to Pick Up work hard to look good. We see them putting on make-up and doing their hair on the train to Warsaw and looking at a mirror, whenever they have the opportunity. Yet, in such moments the camera cruelly exposes their 
blemishes, suggesting that no amount of make-up will be able to erase their original appearance: working class provincials will always remain this way. Their clothes reveal rather than hide their shortcomings and their lack of 'city' manners. Short skirts and tight blouses expose their chubby bodies. One of the girls keeps her fur cap on her head indoors, as if in need to cover herself. To emphasise that provincials in the city look like outsiders more convincing, two of three main female characters were played by amateurs. The reason for that, in my opinion, was to make their unattractiveness more convincing than if they were played by professional actresses. The only girl, played in this group by a professional actress. Ewa Szykulska, has golden crowns on her teeth, although such 'body ornaments', then regarded as extremely tasteless, will be a rarity in the 1970s even among people from the province.

While Goodbye, Till Tomorrow used as its model Godard's film, Girls to Pick Up was influenced by Lásky jedné plavovlásky (A Blonde in Love, 1965) by Czech Miloš Forman, whose films were an important source of inspiration for Kondratiuk throughout his career. In Blonde in Love Forman followed a girl from the province who left her home town for Prague to pursue a piano player who invited her there, only to find that her 'prince' is a womaniser who still lives with his parents, who are quite hostile to the girl. Hence, the trip to the city proves a disappointment for the gullible girl, as is also to Kondratiuk's female characters. However, while Forman's Andula comes across as a dignified individual, whose anguish we share, Kondratiuk creates caricatures, from which we feel inevitably distanced. This reflects the patronising attitude the bulk of Polish filmmakers adopted towards working class provincials in the 1970s. The fact that Kondratiuk's film achieved the status of a cult film, has much to do with the secret communication between the filmmakers and the metropolitan intelligentsia (the target audience of this film), united in their sense of superiority over characters who tried to invade their territory.

The film also shows that it is not easy to have fun and meet suitable partners in Warsaw because the city, at least in winter, when the film is set, is not really a welcoming place for young girls from the province. The streets are cold, so walking them gives one little pleasure and, unlike in Good Bye, Till Tomorrow, Warsaw lacks both interesting buildings which might attract a tourist gaze and (official or unofficial) tourist guides, able and willing to present attractions of the capital to the newcomers. The mise-en-scene and camerawork are mobilised to 'de-tourist' the capital by focusing on the unattractive aspects of the city, such as the nondescript walls of buildings the visitors pass by. Unlike in the tourist brochures, where people are cut out from the pictures not to obscure the beauty of the locations, in Kondratiuk's film long shots are avoided and people, filmed in medium shots or close-ups, obscure what might attract our attention. A café visited by the girls in this film is huge, not allowing for intimate contact, unlike the cosy students clubs and cellars presented in Goodbye, Till Tomorrow and Innocent Sorcerers. There are no other places to socialise, or the girls do not know where to find them. They are also too early for the theatre so when they go there, they only get is glimpse of a famous actor passing through the lobby. Moreover, the girls do not find any boys of a higher class than themselves who are native to Warsaw, but only two men who are menial workers and like the girls came to Warsaw from the province. Warsaw is practically as alien to these 'boys' as it is for the girls, and they cannot offer their partners any interesting way to spend the day. Early on the group ends up in an apartment which belongs to their friend who is better off than the two men thanks to working as a waiter in an up-market restaurant. There the visitors watch television and admire the possessions of the owner, such as bottles of foreign alcohols which, however, on inspection turn out to be filled with a diluted juice. These bottles can be regarded as a metaphor of the 1970s, known as a decade of the propaganda of success, when Poland tried to present itself to the external world as being as technologically and socially advanced as the West (if not more so), but 
behind the façade of success hids something cheap and tasteless, like a diluted juice. As Justyna Jaworska argues, the 'culture of ersatz' permeates consumption in this film, encapsulated by the posh-sounding 'sultan cream' offered in the restaurant, which in reality is whipped cream with some raisins (Jaworska 2014). Ultimately the trip to Warsaw is rather disappointing for the girls. They fail to meet their upper class 'princes' and only one of them has casual sex with the man met in Warsaw. Kondratiuk's film finishes with the girls returning home on the same train, suggesting that they belong to the province - they can visit the city, but not stay there.

\section{Girls in the city; the problem of time and class}

Comparing Polish films about girls in the city from the early 1960s with those from the early 1970s suggests that the 1960s was a decade when women in Polish cinema were most at ease in a city. This reflects the joy about returning to normality after rebuilding the country after the wartime destruction and the end of Stalinism, when the dominant ideology demanded from citizens, irrespective of their gender, to devote all their efforts to the country, regarding any pursuit of private pleasure as trivial and decadent. However, the films show, without admitting it directly, that it is only girls of a higher class who know how to behave in the city in a way that yields them pleasure. By the beginning of the next decade we find more girls in the city who are of a lower class and coming to the city from the provinces. However, the city on this occasion comes across as less welcoming and even a dangerous place. Girls of this kind don't know what to do with themselves in the open space and quickly end up in a private apartment, confirming the view that one has to have a high cultural capital, to be able to consume the city in style. The films discussed in this article, with the exception of Goodbye, See You Tomorrow, also suggest that men are privileged in the city because they own the apartments or have privileged access to them, although housing is a problem for both sexes, reflecting the acute housing shortages Poland suffered post war, up to the present day.

\section{$\underline{\text { Works cited }}$}

Albers, Patricia .C. and William R. James, (1988), 'Travel Photography: a Methodological Approach', Annals of Tourism Research, vol. 15, no 1, pp. 134-58.

Bielicki, Marian (1960), 'Współczuję Morgensternowi', Film, 20, p. 6.

Diski, Jenny (2009), The Sixties, London: Profile Books.

Helman, Alicja (1972), 'Seksolatki na cenzurowanym', Fakty i myśli, 13, p. 10.

Jaworska, Justyna (2014), 'Kłir sułtański w Dziewczynach do wzięcia', Widok: Teorie $i$ praktyki kultury wizualnej, http://pismowidok.org/index.php/one/article/view/161/274Accessed 9 August 2014.

Kurz, Iwona (2010), 'Dziwki, anioły i rycerze a „moment nowoczesny” w polskim kinie po 1956 roku', in Mariusz Zawodnik and Piotr Zwierzchowski (eds), Październik 1956 w literaturze i filmie, Bydgoszcz: Wydawnictwo Uniwersytetu Kazimierza Wielkiego, pp. 220-32.

Lichniak, Zygmunt (1960), 'Listy do kinomanów', Stowo powszechne, no 310, p. 16. Mazierska, Ewa (2015), 'Die Welt berühren: Wanderen-Figuren in den Filmen der polnischen Neuen Welle', in Margarete Wach (ed.), Nouvelle Vague Polonaise? (Marburg: Schüren Verlag), pp. 167-83.

Morawski, Wojciech (2007), 'Poglądy gospodarcze Władysława Gomułki', in Elżbieta Kościk and Tomasz Głowiński (eds), Gospodarka i społeczeństwo w czasach PRL-u, Wrocław: GAJT, pp. 326-332. 
Näripea, Ewa, Ewa Mazierska and Lars Kristensen (2016), 'Gazing at the Baltic: Tourist Discourse in the Cinema of the Baltic Sea Countries', in Simo Mikkonen and Pekka Suutari (eds), Music, Art and Diplomacy: East-West Cultural Interactions and the Cold War (Farnham: Ashgate), pp. 49-66..

Ostrowska, Elzbieta and Joanna Rydzewska, (2007), 'Gendered Discourses of Nation(hood) and the West in Polish Cinema', Studies in European Cinema vol. 4, no. 3, pp. 18798.

Piekarska, Magda (2016). 'Jak się polowało na modę: Rozmowa z Małgorzatą MożdżyńskąNowotką, kuratorką wystawy "Modna i już. Moda w PRL-u"', Gazeta Wyborcza, 17 June, p. 10 .

Różewicz, Tadeusz (1986) [1962], Świadkowie, albo Nasza mała stabilizacja, Kraków: Wydawnictwo Literackie.

Skwara, Janusz (1972). 'Eros i dydaktyka', Barwy, 8, p. 14.

Stawecki, Aleksander (1972). 'Seksolatki na ekranie i wśród nas’, Film, 25, p. 12.

'Uchwała Sekretariatu KC w sprawie kinematografii' (1994), in Tadeusz Miczka and Alina Madej (eds), Syndrom konformizmu: Kino polskie lat sześćdziesiatych (Katowice: Wydawnictwo Uniwersytetu Śląskiego), pp. 27-34.

Wójcik, Grzegorz (2014), 'Emancypacja kobiet w okresie lat 60. i 70. na łamach czasopisma Kobieta i życie’, Kultura Popularna, 2, pp. 118-29.

\footnotetext{
${ }^{\mathrm{i}}$ Hoff also designed costumes for two films, including a television SF film by Andrzej Wajda, Przektadaniec (Roly Poly), which greatly added to a futuristic look of the film.
} 